\title{
Test Kirinyuh Leaf Extract (Euphatorium odoratum.L) as Biofungicides against Antracnose Disease (Colletotrichum capsici) on Chili Plants (Capsicum Annum L)
}

\author{
Asmah Indrawati \\ Faculty of Agriculture, Universitas Medan Area \\ asmah_indrawaty@staff.uma.ac.id
}

\begin{abstract}
Research to determine the effectiveness and concentration of extracts $E$. odoratumas a biofungicide applied to red chilli (C. Annum L) which is attacked by anthracnose (C.capsici). The research was carried out for 4 months from January to April 2020 at the Microbiology Laboratory of the University of North Sumatra, at the UMA Plant Protection Laboratory and in the Experimental Field of the Faculty of Agriculture, Medan Area University. The research was conducted using experimental methods, namely direct experiments and carried out in 2 stages: in vitro and in vivo. In the in vitro research stage, using a completely randomized non-factorial design (CRD Non Factorial) 9 levels with 1 factor which was repeated 3 replications, namely giving E. odoratum extract consisting of: $A F O-=$ negative control (without treatment), $A F O+=$ Control positive $(0.2 \%$ synthetic fungicide), AF1 = PDA media with $10 \%$ E. odoratum extract, AF2 = PDA media with $20 \%$ E. odoratum extract, $A 3=P D A$ media with $30 \%$ E. odoratum extract, AF4 = PDA media with $40 \%$ E. odoratum extract, AF5 = PDA media with $50 \%$ E. odoratum extract, AF6 = $P D A$ media with $60 \%$ E. odoratum extract, AF7 = PDA media with $70 \%$ E. odoratum extract. In the In vivo stage, the experiment used a non-factoral randomized block design (non factorial shelf) with the treatment factor of E. odoratum extract obtained from the results of experiments in vitro in the laboratory, namely the concentration of $0 \%, 50 \%, 60 \%$ and $70 \%$, which is the level of The extract concentration was below the effective concentration and the optimum extract concentration (best from the In vitro results) and the extract concentration was above optimal. Treatment replications and the number of treatment samples to be carried out were based on the results of the concentration to be applied and determined the level in a Non-factorial Randomized Block Design (Non-factorial RBD). ResultIn laboratory experiments showed that the extract was administered E. odoratum with a concentration of $60 \%$ and $70 \%$ significantly suppressed the growth of $C$. capsici colonies up to $0 \mathrm{~cm} 2$. The ability to suppress (inhibit) the growth of $C$. capsici is more effective than the use of synthetic fungicides. In field experiments, it can be concluded that the application of $70 \%$ E. odoratum extract has a very significant effect on fruit production and anthracnose attack intensity.
\end{abstract}

Keywords: extract E. Odoratum; C. Capsici; colletotrichum capsici

\section{Introduction}

The Province of North Sumatra has produced red chili production in the last four years experiencing production fluctuations, namely 2012: 197,411 tons, 2013: 161,933 tons, 2014: 147,812 tons, (National Statistics Agency, 2016). When viewed from the data from the national statistical center agency in 2014, the production of red chili in North Sumatra Province decreased by 14,123 tons or $8.72 \%$ compared to 2013 . One of the causes of the decline in red chili production was anthracnose. Anthracnose is a disease that attacks red chili plants. This disease is caused by the fungus Colletotrichum capsici. 
This fungus is stimulated by humid conditions and relatively high temperatures (AVRDC, 1988). According to (Efri, 2010) stated that the losses caused by this disease reached $70 \%$. Until now, the control of this disease is by using chemical pesticides. Thirty percent of pesticides are disposed of to the ground during the dry season and $80 \%$ in the rainy season are disposed of in the water (Sabarani, 2008). Larvae infected with fungus spores with concentrations of spores / $\mathrm{ml}$ to spores / $\mathrm{ml}$ caused the death of Spodoptera litura larvae up to $83 \%$ on day 12 after infection with fungus spores (Halawa, 2019). .Excessive use of chemical pesticides has a negative impact on the environment and humans. The natural balance is disturbed and will result in resistant pests and threats to predators, parasites, fish, birds and wildlife.

Alternatives in controlling disease among others include using natural ingredients produced as biofungicides, among others. One of the plants that can be used for the therapy of infectious diseases is the leaves of the Euphatorium odoratum L plant. This plant in Thailand is used as a wound medicine, coagulant, and as an antiseptic (Irobi, 1997), in Nigeria it is used as a therapy for malaria (Rungnapa, 2003), while in Indonesia it is used as a medicine for new wounds, fever, cough, and to stop bleeding (Purwati, 2003). Even so, this plant is still very rarely used by the people of Indonesia because it is considered a nuisance plant that is difficult to eradicate. Inya-agha et al (1987) reported that E. odoratum leaf extract contains tannins, phenols, saponins, and its essential oil contains $\alpha$-pinene, cadinene, camphore, limonene, $\beta$-caryophyllene, cadinol isomers.

\section{Review of Literatures}

Owolabi et al (2010) reported the presence of $\beta$-pinene, germacrene, $\beta$-copaen- $4 \alpha$-ol, geijerene. Jane et al (2004) reported the presence of $\alpha$-humulene, $\gamma$-muurolene, bicyclogermacrene, vinylchroman-4-one, and 2- senecioyl-4-vinylphenol in the leaves of $\mathrm{E}$. odoratum. Rungnapa (2003) also informed that the leaves of E. odoratum are rich in flavonoids, quercetin, sinensetin, sakuranetin, padmatine, kaempferol, and salvagenin, isosacuranetin, ramnetin, tamariksetin, kaempferid, and ombuin. Whereas $\beta$-kardinen, sesquiterpenes, $\beta$-sitosterol and triterpene compounds were additionally isolated in the aerial part of this plant. The biological activity of E. odoratum has previously been reported as anodyne, hemostatic, nervine, spasmolytic, vermifuge (James et al., 1989) and antigonorrheal (Armando et al., 1995). Thakong (1999) reported that chloroform extract from E. Odoratum showed high activity against Plasmodium falciparum that was resistant to chloroquin (K1). The compound isolated from the chloroform extract fraction of E. odoratum leaves was isosacuranetin, which was inactive against protozoa $P$. falciparum at a maximum concentration of $5 \mu \mathrm{g} / \mathrm{ml}$. The ethanol extract from the leaves of E. odoratum showed antibacterial activity against Pseudomonas sp., Escherichia coli, B. thuringensis, Klebsiella sp. and Stereptoccocus faecalis (Irobi, 1997). odoratum showed antibacterial activity against Pseudomonas sp., Escherichia coli, B. thuringensis, Klebsiella sp. and Stereptoccocus faecalis (Irobi, 1997). odoratum showed antibacterial activity against Pseudomonas sp., Escherichia coli, B. thuringensis, Klebsiella sp. and Stereptoccocus faecalis (Irobi, 1997).

From the results of previous research that E. Odoratumshows that these plants have secondary metabolite compounds that are active as antibacterial and protozoa. However, the extract biofungicide testE. Odoratumhas not been done and only as a biobactericide and insecticide. Based on these problems, this study aims to determine the effectiveness and concentration of the extractE. Odoratum as a biofungicide applied to Red Chili (C. Annum L) which is attacked by Anthracnose (C. capsici). 


\section{Research Methods}

\subsection{Tools and Materials}

This research was conducted for 4 months from January to April 2020 at the Microbiology Laboratory of the University of North Sumatra, the UMA Plant Protection Laboratory and in the Experimental Field of the Faculty of Agriculture, Medan Area University. The materials used in this study include: leavesE. Odoratum, C.capsici fungi culture, aquades, Acrobat (synthetic fungicide), $70 \%$ alcohol. The tools used in this research include: Laminar air flow, beaker, measuring cup, tweezers, microscope, object glass, petri dish, label paper, ose needle, handsprayer, analytical scale, micropipette, erlyenmeyer flask, oven, incubator. , hot plate stirrer, autoclave and, camera. This research was conducted in 2 stages, namely In vitro and continued with In vivo.

\subsection{Method of Implementation}

The research was conducted using experimental methods, namely direct experiments and carried out in 2 stages: in vitro and in vivo. In the in vitro research stage, using a completely randomized non-factorial design (CRD Non Factorial) 9 levels with 1 factor which was repeated 3 replications, namely giving E. odoratum extract consisting of: $\mathrm{AF0}-=$ negative control (without treatment), $\mathrm{AF0}+=$ Control positive $(0.2 \%$ synthetic fungicide), $\mathrm{AF} 1=\mathrm{PDA}$ media with $10 \% \mathrm{E}$. odoratum extract, $\mathrm{AF} 2=\mathrm{PDA}$ media with $20 \%$ E. odoratum extract, A3 = PDA media with $30 \%$ E. odoratum extract, AF4 = PDA media with E. odoratum extract 40\%, AF5 = PDA media with E. odoratum extract $50 \%$, AF6 = PDA media with E. odoratum extract $60 \%$, AF7 = PDA media with E. odoratum extract $70 \%$.

In the In vivo stage, the experiment used a non-factoral randomized block design (non factorial shelf) with the treatment factor of the extract E. odoratum obtained from the results of experiments in vitro in the laboratory, namely the concentration of $0 \%, 50 \%$, $60 \%$ and $70 \%$, which is the level of extract concentration below the effective concentration and the optimum extract concentration (best from the in vitro results) and the extract concentration above optimal. Treatment replications and the number of treatment samples to be carried out based on the results of the concentration to be applied and determining the level in a Non-factorial Randomized Block Design (Non-factorial RBD)

\subsection{Data analysis}

For the analysis of data from focus groups and semi-direct interviews we used Krueger's method known as "long table" which consisted of identifying thematically or by questions, any word transcribed in the verbatim of the focus groups and semi-direct interviews. We chose to base ourselves on the themes, a method used by Seguin J. (2010). Each word was transcribed when it was relevant, it was classified according to the themes that correspond to those of the grid. The analysis therefore looked at the frequency of similar responses to the same question in 35 target women selected for group discussions and 10 semi-direct interviews. The analysis of these data was supported by observations made at the household level. 


\section{Results Achieved and Specific Potential}

\subsection{Observations in the Laboratory}

\section{a. Provision of C. capsici mushroom}

Sampling was carried out in Kuta Bangun Village, Tiga Binanga District, Karo Regency, by looking at chili plants that were exposed to anthracnose, where according to Rahman (2009), the initial symptoms began with the presence of small black spots and slightly curved on the surface of the fruit. Martoredjo (2010) adds further symptoms of fruit shrinking, rotting and falling, spotting round or sunken and developing on immature fruit, ripe from size. Furthermore, Damm et al (2010) added that the disease can infect the chili stalks from causing spots such as irregular spots with dark red color. Seen in Figure 1.

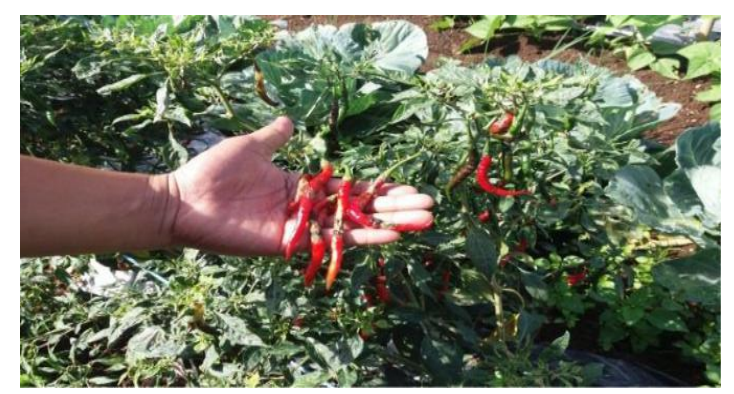

Figure 1. Symptoms of Anthracnose Disease in Chili Fruit Source: Personal Documentation

C. capsici fungi cultures that have been isolated and not contaminated on PDA media are gray with whitish gray mycelium that grows gradually (Fitriani, 2014). It can be seen in Figure A. the conditions of the fungus have not yet experienced complete conidia spread, and in Figure B. it can be seen that the conidia spores of the fungus have fully grown.

The results of the macrocopic identification show that the fungus C. capsici in PDA media in Figure A, it can be seen that the mycelium growth of pure fungal culture colonies has not been seen to be widespread., whereas in Figure B, shows that the fungal culture colonies produce a lot of mycelium, the colonies are white-gray, the colony is dark brown, the growth is slow (3-6 mm in 24 hours), and in old cultures (more than 15 days) black spots appeared on the surface of the $\mathrm{C}$. capsici fungal colonies.

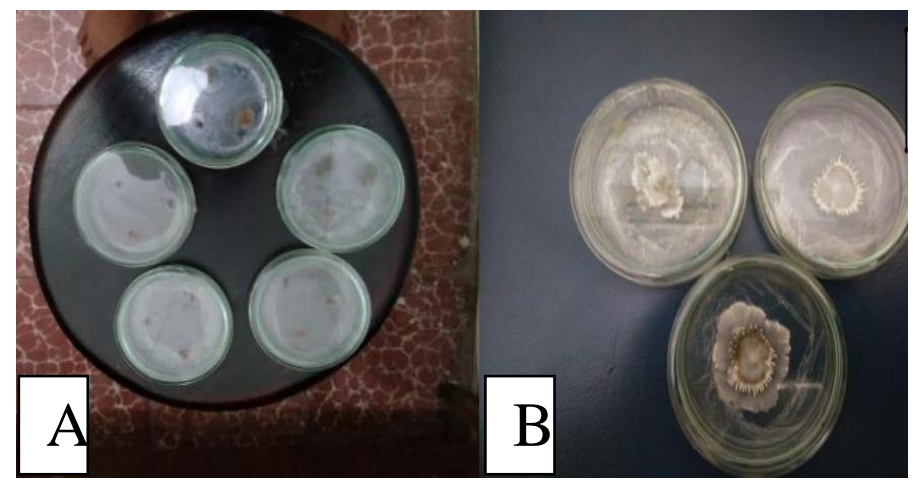

Figure 2. (A) Colony Pure Culture of Colletotricum Capsici fungi Aged 2 Days.

(B) A pure culture colony of Colletotricum capsici fungi aged 7 days

Source: Group Documentation 
From microscopic observation, it was found that the type of Colletotricum fungus, namely C. capsici in Figure 2B, has a cylindrical spore shape with a length of 7-14 $\mu \mathrm{m}$ and a width of 3-5 $\mu \mathrm{m}$, the spores are not septa with hyaline color. Colletotricum Capsici mushroom mycelium. septa and branch. Mckenzie (2013), states that the conidia C. capsici is a whitish gray curved like a crescent moon and ends tapering at both ends, as seen in Figure 3.In the C. acutatum fungus according to AVCRD (2003), states that the fungus C.acutatum has a cylindrical spore shape, tapered tip, spore size $16.1 \times 5.3$ um with a growth speed of $6.8 \mathrm{~mm}$ per day. Sudirga (2016), also states that C. acutatum fungi colonies are in the form of cylindrical spores, the colony color is white gray to blackish brown. Further Dickman (1993) in Sudirga (2016).
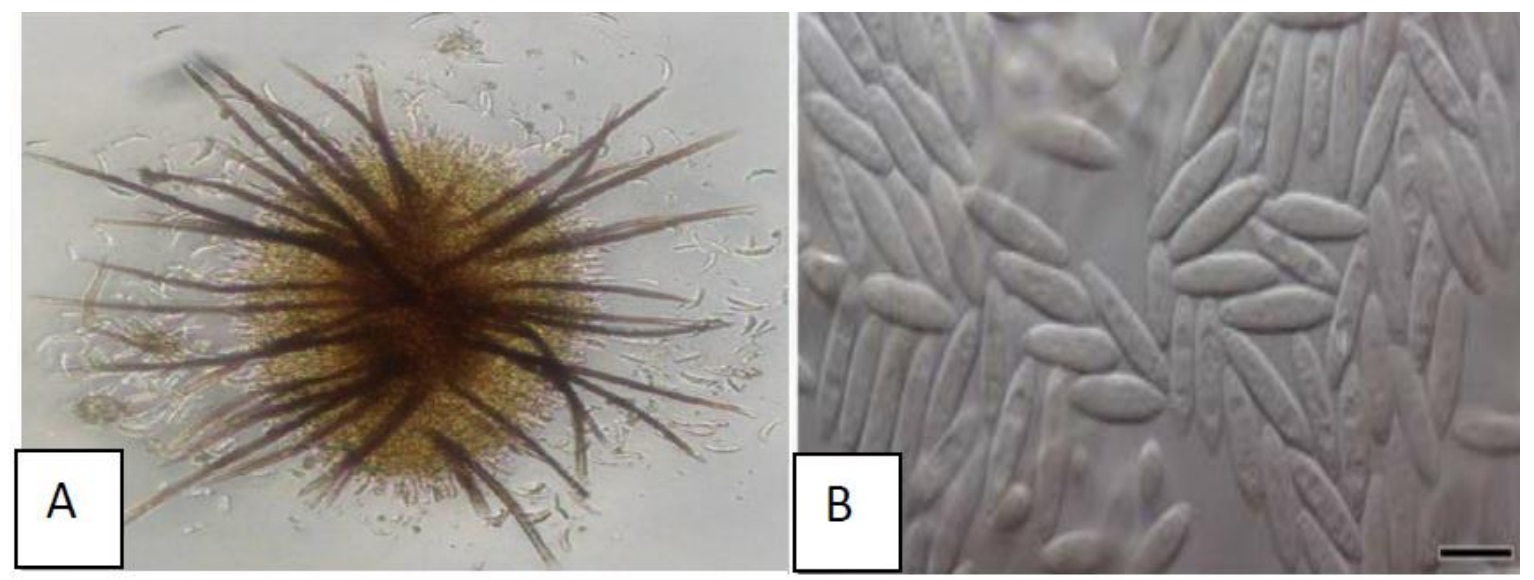

Figure 3. A. Spores of C. capsici fungi. Source: Pratiwi et al (2016). B. Fungal spores of C. acutatum

Source: personal documentation comparing the results of Shivas and Tan (2009).

Based on the picture above, it is obtained two types of Colletotrichum sp. Fungi, and both of them are carried out in vitro development on a petri dish, the observation results show that the faster growth is Colletotrichum capsici. Rompas (2001) states that the temperature required for $\mathrm{C}$. capsici ranges from $24-30^{0} \mathrm{C}$ while $\mathrm{C}$. acutatum grows optimally at 24-26 temperatures ${ }^{0} \mathrm{C}$ (Rosida, 2013). The average temperature in North Sumatra Province is in accordance with the temperature needed by C. capsici mushrooms in its development process, this is supported by BMKG data (2013), which states that the average temperature in North Sumatra Province ranges from 26.5-28. $5^{0} \mathrm{C}$. Wharton and Uribeondo (2004) and Mongkolporn et al. (2010) in Rosida (2013), showed that of the species tested, C. acutatum was the species that had the greatest virulence to chilies at highland temperatures, while according to Syukur (2007) in Ekstiani (2017), it was stated that more than $90 \%$ anthracnose that infects chilies in the lowlands is caused by the fungus Colletotrichum capsici, because of the optimum temperature range for growth. Based on this statement, a development for the invivo test was carried out, in this case the research in the lowlands was Colletotrichum capsici.

\subsection{Bioctivity Test}

\section{a. Growth Percentage of $\mathrm{C}$. capsici mushrooms}

Based on the results of variance, it showed that the application of E. odoratum extract and synthetic fungicides significantly affected the growth percentage of $\mathrm{C}$. capsici. The results of the E. odoratum extract test as a biofunctionality are presented in Table 1 . 
Table 1 shows that the percentage growth of $\mathrm{C}$. capsici colonies shows a very significant difference at the level of $99 \%$. The highest area of inhibition was in the AF + (synthetic fungicide) treatment, which was not significantly different in AF6 $(60 \% \mathrm{E}$. odoratum extract) and AF7 $(70 \%$ E. odoratum extract) where there was no growth of E.odoratum extract colonies. It was significantly different from the AF5 treatment $(50 \% \mathrm{E}$. odoratum extract) and very significantly different from the AF4 treatment $(40 \% \mathrm{E}$. odoratum extract), AF3 (30\% E.odoratum extract), AF2 (20\% E.odoratum extract), AF1 $(10 \%$ E. odoratum extract) and AF- (without synthetic fungicide treatment and $\mathrm{E}$. odoratum extract) which were the lowest inhibition for all C.capsici colonies.

Table 1. Effect of E. odoratum Extract on Growth Percentage of C. capsici.

\begin{tabular}{c|c|c|c}
\hline \multirow{2}{*}{ Treatment } & & \multicolumn{2}{|c}{ Percentage Grow (\%) } \\
\cline { 2 - 4 } & Average & Notation \\
\cline { 2 - 4 } & & F 0.05 & F 0.01 \\
\hline AF- & 100.00 & $\mathrm{c}$ & $\mathrm{B}$ \\
$\mathrm{AF}+$ & 0.00 & $\mathrm{a}$ & $\mathrm{A}$ \\
$\mathrm{AF} 1$ & 100.00 & $\mathrm{c}$ & $\mathrm{B}$ \\
$\mathrm{AF} 2$ & 100.00 & $\mathrm{c}$ & $\mathrm{B}$ \\
$\mathrm{AF} 3$ & 100.00 & $\mathrm{c}$ & $\mathrm{B}$ \\
$\mathrm{AF} 4$ & 66.67 & $\mathrm{~b}$ & $\mathrm{~B}$ \\
$\mathrm{AF5}$ & 33.33 & $\mathrm{~b}$ & $\mathrm{AB}$ \\
$\mathrm{AF} 6$ & 0.00 & $\mathrm{a}$ & $\mathrm{A}$ \\
$\mathrm{AF} 7$ & 0.00 & $\mathrm{a}$ & $\mathrm{A}$ \\
\hline
\end{tabular}

Note: Numbers followed by the same letter in the same column show insignificant differences at the $99 \%$ (lowercase) and 99\% (uppercase) levels

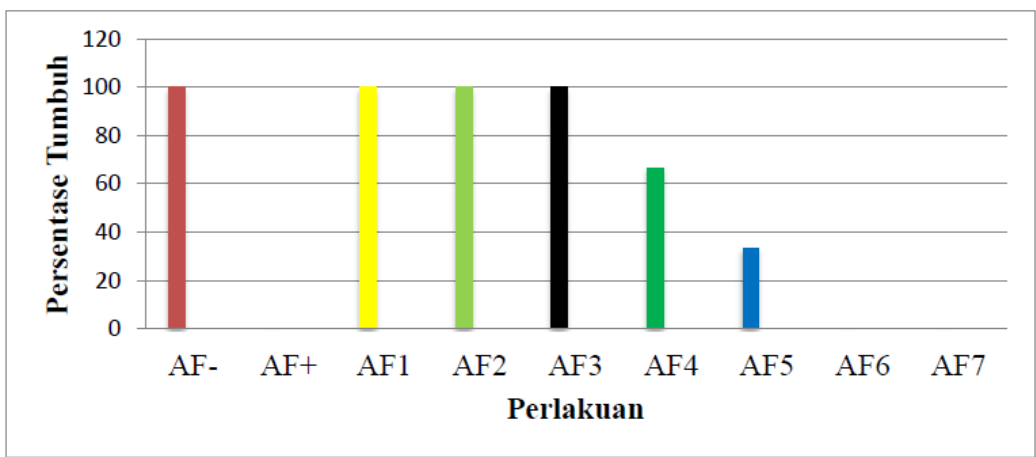

Figure 4. Graph of E. Odoratum extract application to growth percentage of C. capsici

Data were collected at three days after inoculation to see signs of early growth marked by white mycelium on all treated media. Treatment of synthetic fungicides and extracts of E. odoratum $60 \%$ and E. odoratum $70 \%$ in (Figure 4) shows that there is inhibition of E. odoratum extract, so there are no signs of growth marked mycelium.

This is because the compounds contained in E. odoratum can inhibit the growth of $\mathrm{C}$. capsici. Where that the content of E. odoratum contains secondary metabolites, including flavonoids, saponins, tannins, alkaloids, and steroids / triterpenoids. This is in accordance with the statement conveyed by Parubak, AS, 2013) which states that flavonoid compounds have a number of uses. First, against plants, namely as a plant regulator, a photosynthetic regulator, and can be used as a vegetable pesticide because it acts as an antimicrobial and antiviral agent. 


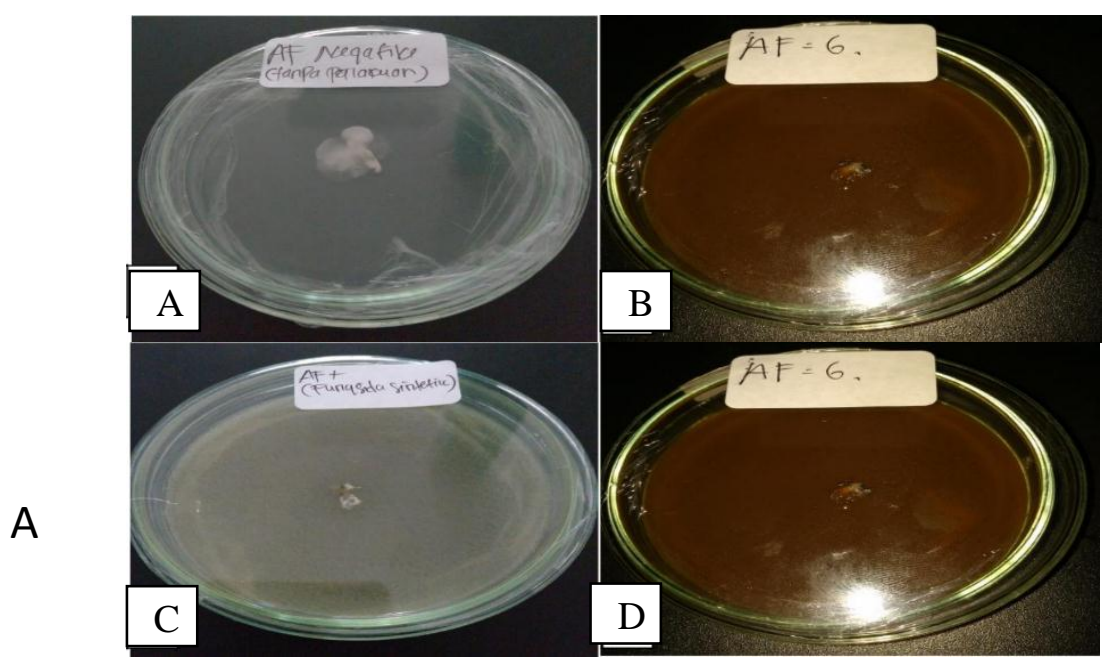

Figure 5. Capsici Mushroom Colony Growth Percentage Due to Synthetic Fungicide Application (C), C.capsici mushroom colony Growth Percentage Due to 60\% E. odoratum extract (B and D) and Untreated Colony Growth Percentage (Negative Control) ( A) Source: Group Documentation

This was also proven in the research of Purwati and Undri Rastuti (2009) which explained that Euphatorium odoratum leaf ethyl acetate extract was based on screening of secondary metabolites containing flavonoids, with secondary metabolites in the ethyl acetate extract of Euphatorium odoratum leaves having antioxidant activity with an inhibitory activity sequence of $0,15 \%$. Hadi's research (2008) explains that the presence of kirinyuh leaf extract on paper causes anti and causes termites to reduce the amount of food consumed so that termites experience mortality. Kiriyuh leaf extract (Euphatorium odoratum) on paper is also toxic to termites, so it can be used as a control for Coptotermes sp. The concentration of kirinyuh leaf extract on paper which is effective (LC-50) as a termite control agent is at a concentration of 2.Robinson (1995) also states that the tannin compounds contained in E. odoratum are antibacterial, Robinson's statement (1995) is strengthened by research (Nurussakinah, 2010) that the ethanol extract of E. odoratum can be used as antibacterial against Streptococcus mutans and Eschericia coli. While antifungal compounds, one of which is saponins, saponins contained in E. odoratum can be antibacterial and anti-fungal, which according to (Osbourn et al 1996) the presence of saponins can be an indicator of the resistance of a plant species to fungal infection, this statement is strengthened by the statement (Sugianitri, 2011) ) Saponins are surfactants that are polar in shape so that they will break down the fat layer on the cell membrane which in turn causes interference with cell membrane permeability.

\section{b. Extract Inhibition Zone E. odoratum Against C. capsici Mushrooms.}

Based on the results of variance, it showed that the application of E. odoratum extract and synthetic fungicides significantly affected the growth percentage of $\mathrm{C}$. capsici. The results of the E. odoratum extract test as a biofunctionality are presented in Table 2. Based on Table 2, it shows that the treatment of E. odoratum extract can inhibit the growth of $\mathrm{C}$. capsici fungi where the best treatment is at concentrations of AF6 $(60 \%)$ and AF7 (70\%), both 95\% confidence level and 99\% good at the age of 4-10 DIC . In the observation of 4 DICs, it showed that the application of synthetic fungicides could inhibit the growth of C. capsici fungi. However, at the age of 5-10 HSI C. capsici was able to grow on synthetic fungicides and did not grow on E. odoratum extract and did not cause resistance. 
Table 2. Effect of E. Odoratum Extract on Inhibited Jona C. capsici Fungus aged 4-10 HSI (Transformation Result $\sqrt{\mathrm{x}}+0.5$ ).

\begin{tabular}{|c|c|c|c|c|c|c|c|}
\hline \multirow[b]{2}{*}{ Per } & \multicolumn{5}{|c|}{$\begin{array}{l}\text { Mushroom mycelium growth of C. } \\
\text { capsici }\end{array}$} & \multirow[b]{2}{*}{9 HSI } & \multirow[b]{2}{*}{$10 \mathrm{HSI}$} \\
\hline & 4 HSI & $5 \mathrm{HSI}$ & $6 \mathrm{HSI}$ & 7 HSI & 8 HSI & & \\
\hline AF- & $1.51 \mathrm{~d} \mathrm{D}$ & 1.56 e $\mathrm{D}$ & 1.62 e $E$ & $1.73 \mathrm{~d} \mathrm{C}$ & $1.75 \mathrm{~d} \mathrm{D}$ & $1.79 \mathrm{~d} \mathrm{D}$ & 1.79 e D \\
\hline $\mathrm{AF}+$ & 1.10 a A. & $1.20 \mathrm{~b} \mathrm{~B}$ & $1.31 \mathrm{cb} \mathrm{CB}$ & $1.40 \mathrm{~b} \mathrm{~B}$ & 1.44 b B & $1.47 \mathrm{~b} \mathrm{~B}$ & 1.48 b B \\
\hline AF1 & $1.34 \mathrm{c} \mathrm{C}$ & $1.37 \mathrm{~d} \mathrm{C}$ & $1.40 \mathrm{~d} \mathrm{D}$ & $1.53 \mathrm{c} \mathrm{B}$ & $1.54 \mathrm{c} \mathrm{C}$ & 1.56 с C & $1.58 \mathrm{~d} \mathrm{C}$ \\
\hline AF2 & $1.33 \mathrm{c} \mathrm{C}$ & $1.36 \mathrm{~d} \mathrm{C}$ & $1.42 \mathrm{~d} \mathrm{D}$ & $1.53 \mathrm{c} \mathrm{B}$ & $1.55 \mathrm{c} \mathrm{C}$ & $1.56 \mathrm{c} \mathrm{C}$ & $1.59 \mathrm{~d} \mathrm{C}$ \\
\hline AF3 & $1.33 \mathrm{c} \mathrm{C}$ & $1.36 \mathrm{~d} \mathrm{C}$ & $1.41 \mathrm{~d} \mathrm{D}$ & $1.51 \mathrm{c} \mathrm{B}$ & $1.52 \mathrm{c} \mathrm{C}$ & $1.54 \mathrm{c} \mathrm{C}$ & $1.57 \mathrm{dcC}$ \\
\hline AF4 & $1.31 \mathrm{c} \mathrm{C}$ & $1.33 \mathrm{~d} \mathrm{C}$ & $1.36 \mathrm{c} \mathrm{DC}$ & $1.48 \mathrm{cb} \mathrm{B}$ & $1.48 \mathrm{cb} \mathrm{CB}$ & $1.51 \mathrm{bc} \mathrm{BC}$ & $1.53 \mathrm{cb} \mathrm{CB}$ \\
\hline AF5 & $1.26 \mathrm{~b} \mathrm{~B}$ & $1.26 \mathrm{c} \mathrm{B}$ & $1.26 \mathrm{~b} \mathrm{~B}$ & $1.40 \mathrm{~b} \mathrm{~B}$ & 1.42 b B & $1.46 \mathrm{~b} \mathrm{~B}$ & $1.48 \mathrm{~b} \mathrm{~B}$ \\
\hline AF6 & 1.10 a A. & $1.10 \mathrm{a} \mathrm{A}$. & 1.10 a A & $1.10 \mathrm{a} \mathrm{A}$. & 1.10 a A. & 1.10 a A. & $1.10 \mathrm{a} A$. \\
\hline AF7 & $1.10 \mathrm{a} \mathrm{A}$. & $1.10 \mathrm{a} A$. & 1.10 a A. & 1.10 a A. & 1.10 a A. & 1.10 a A. & 1.10 a A. \\
\hline
\end{tabular}

Note: Numbers followed by the same letter in the same column show insignificant differences at the $95 \%$ (lowercase) and 99\% (uppercase) levels

This is in accordance with the statement conveyed by Etmawati (2016), that excessive use of chemicals and exposure for too long will cause the generation of pests or diseases to become resistant to chemicals, in contrast to the treatment of E. odoratum extract which causes $\mathrm{C}$. capsici fungi to not. able to grow or not to cause resistance. This is in line with Untung's (2006) statement, which states that the use of organic pesticides does not cause pests and diseases to become immune. This can be seen in the response curve of the relationship between the administration of E. odoratum extract and the mycelium diameter of the C. capsici fungi aged 8 HSI is presented in Figure 6.

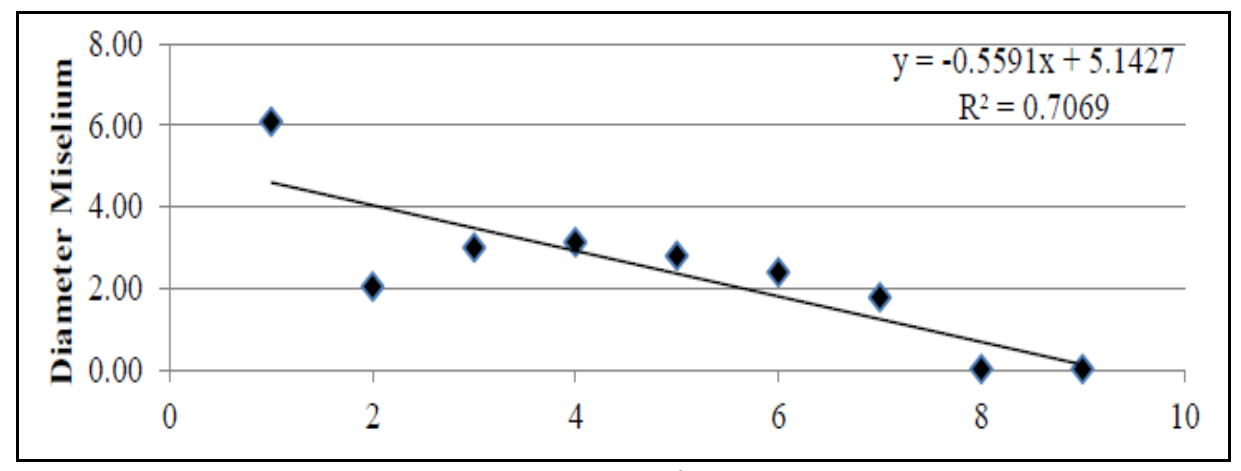

Giving Extract E. odoratum

Figure 6. Response curve of the relationship between E. odoratum extract and $C$. capsici mushroom mycelium diameter at 8 DID

From Figure 6, it can be seen that the response curve shape of the relationship between $\mathrm{E}$. odoratum extract and $\mathrm{C}$. capsici mushroom mycelium diameter is linear, with the equation: $\mathrm{Y}=-0.55991 \mathrm{x}+0.51427$. Regression coefficient value $\left(\mathrm{R}^{2}\right)=0.7069$ explained that $70 \%$ inhibition of the growth of $\mathrm{C}$. capsici fungi mycelium was due to the $\mathrm{E}$. odoratum extract with the best treatment, namely AF6 (60\%) and AF7 (70\%). This is because the content of secondary metabolic compounds found in E. odoratum can inhibit the growth of the fungal mycelium C. capsici, which according to Naim (2004), which 
states that secondary metabolic found in plants is self-defense against microorganisms (bacteria, fungi, protozoa), insects and herbivores. According to (Arifin 2014; Rahayu and Pukan, 1998) that the content of E. odoratum contains secondary metabolites, including flavonoids, saponins, tannins, alkaloids, and steroids / triterpenoids. According to Parubak, AS, (2013), which states that flavonoid compounds have a number of uses. First, for plants, namely as a plant regulator,

Robinson (1995) also states that the tannin compounds contained in E. odoratum are antibacterial, Robinson's statement (1995) is strengthened by research (Nurussakinah, 2010) that the ethanol extract of $\mathrm{E}$. odoratum can be used as antibacterial against Streptococcus mutans and Eschericia coli. While antifungal compounds, one of which is saponins, saponins contained in E. odoratum can be antibacterial and anti-fungal, where according to Osbourn et al. 1996, the presence of saponins can be an indicator of the resistance of a plant species to fungal infection, this statement is strengthened by the statement (Sugianitri, 2011 ) Saponins are surfactants that are polar in shape so that they will break down the fat layer on the cell membrane which in turn causes interference with cell membrane permeability.

\subsection{In Vivo Observations. a. Chili Fruit Production}

Based on the results of variance, it showed that the administration of E. odoratum extract and synthetic fungicides significantly affected the production of chili fruit. The results of the test for the variety of $\mathrm{E}$. odoratum as a biofunctional acid are presented in Table 6.Based on Table 6 shows that the best treatment for chili plant production at the 1st and 2nd harvests was found in AF3 treatment (70\%) of E. odoratum extract which was not different. significantly with AF2 treatment $(60 \%)$ of E. odoratum extract compared with $\mathrm{AF} 1$ treatment $(50 \%)$ of $\mathrm{E}$. odoratum extract, $\mathrm{AF}+$ synthetic fungicide, and $\mathrm{AF}$ - without treatment with either $95 \%$ or $99 \%$ confidence levels.

Table 3. Effect of E. odoratum Extract on Chili Fruit Production from the 1st and 2nd Harvest (Transformation Results $\sqrt{ } \mathrm{x}+0.5$ )

\begin{tabular}{ccc}
\hline & \multicolumn{3}{c}{ Chili Fruit Production } \\
\cline { 2 - 3 } Per & 1st Harvest & 2nd Harvest \\
\hline AF- & 1.99 c B & 2.18 c C \\
AF + & 2.82 ab A. & 2.70 b B \\
AF1 & 2.74 b A & 2.72 b B \\
AF2 & 2.91 a A. & 3.18 a A. \\
AF3 & 3.09 a A. & 3.18 a A. \\
\hline
\end{tabular}

Note: Numbers followed by the same letter in the same column show insignificant differences at the $95 \%$ (lowercase) and 99\% (uppercase) levels.

This is because the content of secondary metabolic compounds found in E. odoratum can inhibit the growth of the fungal mycelium C. capsici, which according to Naim (2004), which states that secondary metabolic found in plants is self-defense against microorganisms (bacteria, fungi, protozoa), insects and herbivores. According to (Arifin 2014; Rahayu and Pukan, 1998) that the content of E. odoratum contains secondary metabolites, including flavonoids, saponins, tannins, alkaloids, and steroids / triterpenoids. According to Parubak, AS, (2013), which states that flavonoid compounds have a number of uses. 


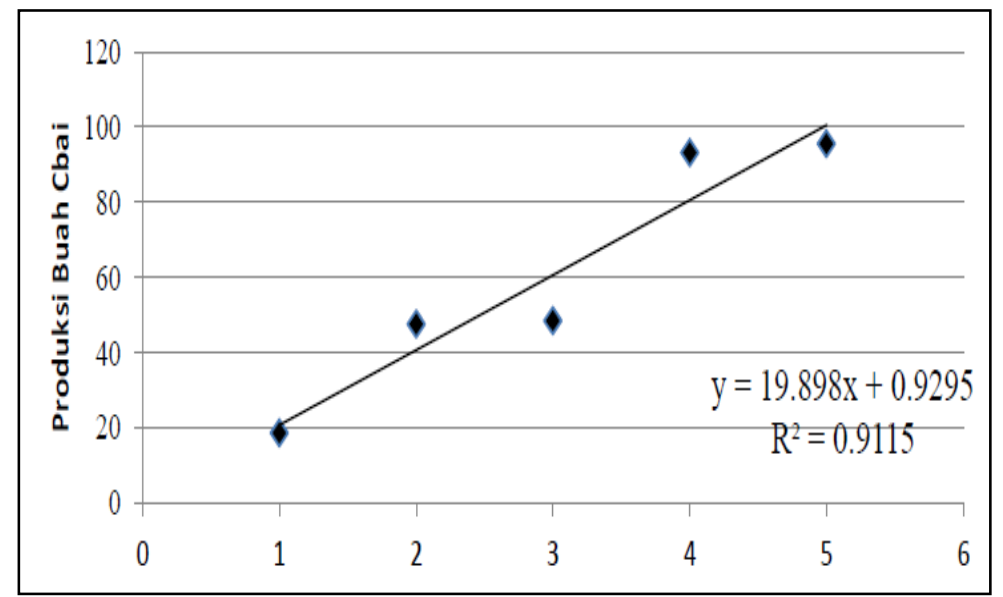

$\mathrm{v}$ Administration of E. Odoratum Extract

Administration of E. odoratum extract

Figure 7. Response Curve of the Relationship Between Giving E. odoratum Extract to the Production of Chili Plants at the 2nd Harvest

From Figure 7 it can be seen that the shape of the response curve of the relationship between E. odoratum extract and chili fruit production is linear, with the equation: $\mathrm{Y}=$ $19,898 x+0.9295$. The regression coefficient value $\left(R^{2}\right)=0.9115$ explains that $91.15 \%$ good chili fruit production is caused by the best treatment of E. odoratum extract, namely AF6 (60\%) and AF7 (70\%). According to Ariyanti et al (2012), states that phenolic compounds found in plants will cause lysis of microbial cells as well as the content of phenol compounds in E. odoratum. According to Prindle and Wright (1971) in Ariyanti et al (2012), adding that if the microbial cell is damaged, toxins from the cell can enter and result in reduced essential metabolites needed by microbes, phenolic compounds as antimicrobials are active against vegetative microbial cells.

At the time of observation, it shows that the $\mathrm{pH}$ is close to normal, namely 6.5 with an average temperature of $28.5^{0}-31^{0} \mathrm{C}$. According to Widiastoety (1986), states that to absorb certain nutrients requires a $\mathrm{pH}$ ranging from 5.0-6.5, whereas if the $\mathrm{pH}$ is too low $(<4.5)$ or the $\mathrm{pH}$ is too high $(>7.0)$ it can inhibit plant growth. This will result in the susceptibility of plants to pests and plant diseases. One of the nutrients needed in the formation of fruit is phosphorus. This is consistent with the statement given by Rubatzky and Yamaguchi (1998), which states that plants require $\mathrm{P}$ at all levels of growth and flowering. The role of phosphorus is not only that, according to Rismunandar (1990) in plants, phosphorus is used in the formation of protein, especially in the metabolic transfer of ATP, ADP, photosynthesis, and respiration, and is included in the components of phospholipids. the role of other phosphorus in the formation of roots, accelerate the ripening of fruit and strengthen the body of root plants not susceptible to pests and diseases. In the observation, the average temperature in the field ranged from $28.5^{0}-31^{0} \mathrm{C}$, with such a high temperature the $\mathrm{C}$. capsici fungus cannot grow properly, which according to Ekstiani (2017) states that anthracnose disease is widespread due to humid conditions and relatively low temperatures. This is in accordance with Marpaung (2016), which states that for the growth and development of disease-causing microbes in plants, it must be in accordance with the desired temperature conditions in the field. 


\section{b. Attack Intensity}

The intensity of anthracnose attack is the percentage ratio of the number of fruit harvested to the number of fruits attacked by anthracnose. Based on the results of variance, it showed that the administration of E. odoratum extract and synthetic fungicides significantly affected the intensity of the attack. The results of the assay of the variety of $\mathrm{E}$. odoratum extract as a biofunctional acid are presented in Table 7 which shows that the best treatment of attack intensity at the 1st and 2nd harvests was found in AF3 treatment $(70 \%)$ of E. odoratum extract which was not different from AF2 treatment ( 60\%) E. Odoratum extract was compared with AF1 treatment (50\%) E. odoratum extract, AF + synthetic fungicide, and AF- without treatment with either $95 \%$ or $99 \%$ confidence levels.

Table 4. Effect of E. odoratum Extract on Attack Intensity

From the 1st Harvest and 2nd Harvest (Transformation Result $\sqrt{\mathrm{x}}+0.5$ ).

\begin{tabular}{ccc}
\hline & \multicolumn{2}{c}{ Chili Fruit Production } \\
\cline { 2 - 3 } Per & 1st Harvest & 2nd Harvest \\
\hline AF- & $2.12 \mathrm{c} \mathrm{B}$ & $2.06 \mathrm{c} \mathrm{B}$ \\
$\mathrm{AF}+$ & $1.40 \mathrm{~b} \mathrm{~A}$ & $1.49 \mathrm{~b} \mathrm{AB}$ \\
$\mathrm{AF} 1$ & $1.56 \mathrm{~b} \mathrm{AB}$ & $1.63 \mathrm{cb} \mathrm{B}$ \\
$\mathrm{AF} 2$ & $1.39 \mathrm{~b} \mathrm{~A}$ & $1.18 \mathrm{ab} \mathrm{A}$ \\
$\mathrm{AF3}$ & $0.97 \mathrm{a} \mathrm{A}$. & $0.97 \mathrm{a} \mathrm{A}$.
\end{tabular}

Note: Numbers followed by the same letter in the same column show insignificant differences at the $95 \%$ (lowercase) and 99\% (uppercase) levels.

In the AF-treatment, chilies had the highest anthracnose attack intensity value. This was due to the AF treatment- the absence of phenolic compounds, alkaloids, flavonoids, saponins was given so that the intensity of anthracnose attacks was greater than the other treatments. According to Dewi et al (2013), which states that secondary metabolic compounds including phenols, flavonoids, and saponins are compounds that damage cell walls. Dewi et al (2013) added that the cell wall as a component of bacterial cell defense was damaged so that secondary metabolites could enter deeper and disturb other organelles. The response curve of the relationship between giving E. odoratum extract to the production of chili plants at the second harvest is presented in Figure 8.

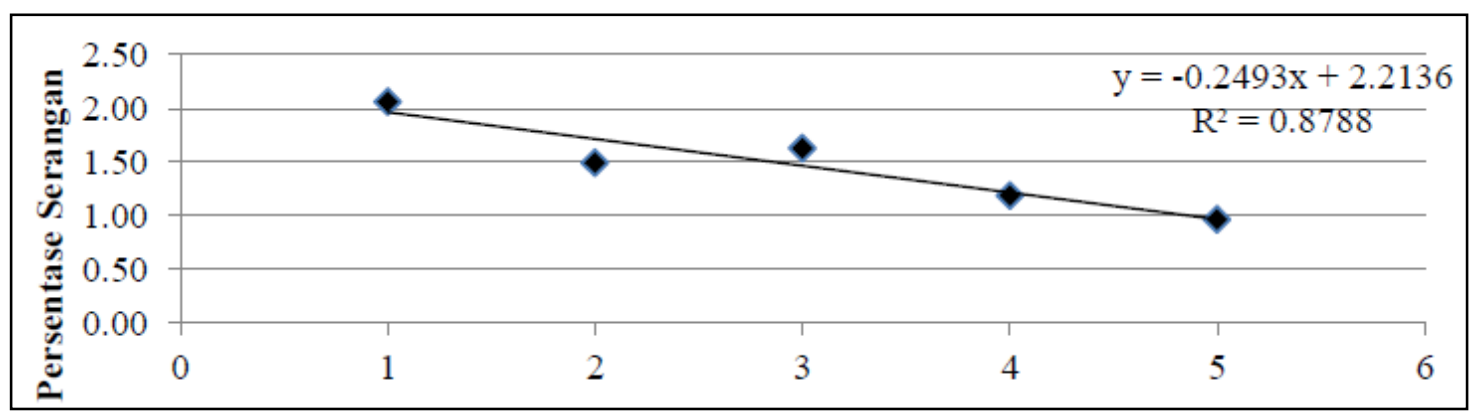

Figure 8. Correlation Response Curve Between Giving E. odoratum Extract Against Attack Intensity at the 2nd Harvest 
From Figure 8 it can be seen that the shape of the response curve of the relationship between the giving of $\mathrm{E}$. odoratum extract and the percentage of attacks is linear, the equation: $\mathrm{Y}=-0,2493 \mathrm{x}+2,2136$. The value of the regression coefficient $\left(\mathrm{R}^{2}\right)=0.8788$ explains that $87.88 \%$ good chili fruit production is caused by the best treatment of $\mathrm{E}$. odoratum extract, namely AF6 (60\%) and AF7 (70\%), indicating that the higher the E. odoratum extract, the lower the fruit who are stricken with anthracnose, this is because the higher the dose, the higher the content of secondary metabolite compounds. This is in accordance with the statement conveyed by Hartati (2012), which states that the weaknesses of essential oil-based pesticides are related to the properties of the essential oil itself which are volatile and unstable or not resistant to sunlight.

According to Ariyanti et al (2012), states that phenolic compounds found in plants will cause lysis of microbial cells as well as the content of phenol compounds in $\mathrm{E}$. odoratum. According to Prindle and Wright (1971) in Ariyanti et al (2012), adding that if the microbial cell is damaged, toxins from the cell can enter and result in reduced essential metabolites needed by microbes, phenolic compounds as antimicrobials are active against vegetative microbial cells.

\section{c. Special Potential}

The results of the analysis of this study were to determine the best quality of E. odoratum extract, the more E. odoratum extract that was applied to anthracnose-stricken chili plants, the more effective it was in controlling C. capsici fungi that attacked chili plants. From the results of this study, it is hoped that it can become a reference for farmers in controlling anthracnose so as to reduce yield losses. The results of this study can also reduce the environmental impact of pollution from the use of synthetic fungicides in controlling anthracnose disease.

\section{Conclusion}

1. In laboratory experiments, it can be concluded that the administration of E. odoratum extract with a concentration of $60 \%$ and $70 \%$ significantly suppressed the growth of $\mathrm{C}$. capsici colonies up to $0 \mathrm{~cm}^{2}$. The ability to suppress (inhibit) the growth of $\mathrm{C}$. capsici is more effective than the use of synthetic fungicides.

2. In the field experiment, it was concluded that the application of E. odoratum extract had a very significant effect on the parameters of fruit production and the intensity of attacks at the 1 st and 2 nd harvests.

\section{References}

Ambarningrum,T.B., Arthadi, P. Hery, dan P. Slamet. 2007. Ekstrak E. Odoratum (Pithecellobium lobatum): PengaruhnyaSebagai Anti Makan Dan Terhadap Efisiensi Pemanfaatan Makanan Larva Instar V Heliothis armigera. J. Sains MIPA13:165-170

Arthadi, P. Hery, dan P. Slamet. 2007. Ekstrak E. Odoratum (Pithecellobium lobatum): Pengaruhnya Sebagai Anti Makan Dan Terhadap Efisiensi Pemanfaatan Makanan Larva Instar V Heliothis armigera. J. Sains MIPA13:165-170

AVRDC. 1988. Growth Characters and Inoculation Methods of Antrachnose Pathogens. p : 67-70. AVRDC Progress Report 1988. Taiwan.

AVRDC. 2003. Evaluation Of Phenotypic And Molecular Criteria For The Identification Of Colletotricum Spesies Causing Pepper Antraknose In Taiwan. 
Badan Meteorologi Klimatologi dan Geofisika. 2013. Buku Informasi Perubahann Iklim dan Kualitas Udara di Indonesia. Pusat Perubahan Iklim Dan Kualitas Udara Kedeputian Bidang Klimatologi Badan Meteorologi, Klimatologi Dan Geofisika

Badan Pusat Statistik Nasional. 2016. Data Produksi Sayuran Cabai Besar (ton). http//www.bps.go.id./site/result Tab. Diakses pada 31 oktober 2016.

Damm U, Cannon PF, Woundenberg JHC, Crous PW. 2012. The Colletotrichum acutatum species complex. Studies in Mycology 73:37-113.

Dwei,ID.A.D.Y., Astuti,K.WIWardtiani,N.K.2013. Skrining Fitokimia Ekstrak Kulit Manggis (Gracia mangostana L). Skripsi. Fakultas Matematika Ilmu Pengetahuan Alam Universitas Udayana Bali.

Efri. 2010. Pengaruh Ekstrak Berbagai Bagian Tanaman Mengkudu (Morinda citrifolia) Terhadap Perkembangan Penyakit Antraknosa Pada Tanaman Cabe (Capsicum annuum L.). Lampung. Jurusan Proteksi Tanaman, Fakultas Pertanian, Universitas Lampung. J. HPT Tropika. ISSN 1411-7525. Vol. 10, No. 1: $52-58$

Ekstiani Vicha Nerica (2017). 2017. Upaya Pengendalian Jamur Colletotrichum capsici (Syd) Butler \& Bisby. Penyebab Antraknosa Dengan Menggunakan Ekstraksi Buah Leunca (Solanum nigrum L) pada tanaman cabai (Capsicum annuum). Fakultas MIPA Universitas Lampung.

Fitriani Melly.2014. Mikrobiota Pada Buah Cabai: Pengaruhnya Terhadap Colletotrichum capsici, Cendawan Penyebab Antraknosa. Departemen Biologi Fakultas Matematika Dan Ilmu Pengetahuan Alam Institut Pertanian Bogor

Halawa, B., Azwana, and Panggabean, E.L. (2019). Sensitivity of Larva Spodoptera litura Against the Density of Spores of Fungi Metarhizium anisopliae on the Onion Plant Red (Allium cepa) in the Laboratory. Budapest International Research in Exact Sciences (BirEx) Journal Vol I (1): 35-41.

Hartati.S.Y.2012.Prospek Pengembangan Minyak Atsiri Sebagai Pestisida Nabati.Prespektif, 11(1),45-58

McKenzi, Eric. 2013.Colletotrichum capsici. http $/ /$ www.padil.gov.au/mafborder/pest/main/143014/51022 diakses pada tanggal 14 Juni 2017.

Naim, R. 2004. Senyawa Antimikroba dari Tanaman. http://www.kem.com/sorotan/126564htm. Diakses Pada 26 Juli 2016

Ningsih Riana Dian, Zusfahair dan Dwi Kartika. 2016. Identifikasi Senyawa Metabolit Sekunder Serta Uji Aktifitas Ekstrak Daun Sirsak Sebagai Antibakteri. Jurnal Molekul, Vol.11. No1

Nurussakinah. 2010. Skrinning Fitokimia dan Uji Aktivitas Antibakteri Ekstrak Kulit Buah Tanaman Jengkol (Pithecellobium jiringa (Jack) Prain) Terhadap Bakteri Streptococcus mutans, Staphylococcus aureus, dan Eschericia coli, Skripsi, Fakultas Farmasi, USU, Medan. 45

Osbourn AE. Preformed antimicrobial compounds and plant defense againts fungal attack. Plant Cell.8: 1821-1831,1996.

Pradani F. Y. 2009. Indeks Pertumbuhan Larva Aedes aegypti L. Yang Terdedah Dalam Ekstrak Air E. odoratum (Pithecellobium lobatum). Aspirator. 1 (2): 81-86.

Pratiwi Wahyu Nova, Erwina Juliantari, dan Lutfi Khotun Napsiyah. 2016. Identifikasi Jamur Penyebab Penyakit Pascapanen pada

Beberapa Komoditas Bahan Pangan. Jurnal Riau Biologia 1 (14):86-94

Rahman Benny. 2009. Uji Beberapa Konsentrasi Ekstrak Daun Mimba (Azadirachata indica A. Juss) Untuk Pengendalian Penyakit Antraknosa Pada Buah Cabai (Capsicum annum) Pascapanen. Program Studi Ilmu Hama Dan Penyakit Tumbuhan Jurusan Budidaya Pertanian Fakultas Pertanian Universitas Riau. 
Ratulangi M.M. Sembel, D.T. C.S. Rante .M.F. Dien.E.R.M. Meray M. Hammig. M. Shepard. G. Carner. dan E. Benson. 2012. Diagnosis dan Insidensi Penyakit Antraknosa Pada Beberapa Varietas Tanaman Cabe Di Kota Bitung Dan Kabupaten Minahasa. Jurnal Eugenia Volume 18 No. 2.

Robinson, T. (1995). Kandungan Organik Tumbuhan Tinggi. Penerjemah: Padmawinata, K. Edisi VI. Bandung: ITB Press.

Rosidah Syaidatul. 2013. Pendugaan Parameter Genetik Ketahanan Terhadap Penyakit Antraknosa Dan Beberapa Karakter Kuantitatif Pada Cabai. Departemen Agronomi Dan Hortikultura Fakultas Pertanian Institut Pertanian Bogorl

Rubatzky ,V.E. dan M.Yamaguchi, 1998.Sayuran Dunia 2 Prinsip. Produksi dan Gizi. ITB Bandung

Sabarani M Friska. 2008. Uji Efektivitas Beberapa Pestisida Nabati untuk Mengendalikan Penyakit Antraknosa (Colletotrichum capssci) Pada Tanaman Cabai (Capsicum annum L) Di Lapangan.Skripsi. Medan. Departemen Ilmu Hama dan Penyakit Tumbuhan. Fakultas Pertanian Universitas Sumatera Utara.

Semangun, H. 2007. Penyakit-Penyakit Tanaman Hortikultura di Indonesia. Gajah Mada University Press. Yogyakarta.

Soelaiman, V dan Ernawati A. 2013. Pertumbuhan dan Perkembangan Cabai Keriting (Capsicum annuum L.) secara In vitro pada beberapa Konsentrasi BAP dan IAA. Bul. Agrohorti 1 (1) : 62-66.

Suadi. 2014. Mengubah Sampah Menjadi Berkah. http://www.medanbisnisdaily.com/news/read/2014/03/03/87942/.diakses pada 8 September 2016

Sudirga Ketut Sang. 2016. Isolasi Dan Identifikasi Jamur Colletotrichum spp. Isolat Pcs Penyebab Penyakit Antraknosa Pada Buah Cabai Besar (Capsicum annuum L.) Di Bali. Jurnal Metamorfosa III (1): 23-30 ISSN . 2302-5697

Sugianitri, N. K. 2011. Ekstrak Biji Buah Pinang (Areca catechu L.) dapat Menghambat Pertumbuhan Koloni Candida albicans secara In Vitro pada Resin Akrilik Heat Cured. Tesis. Program Pascasarjana Program Studi Ilmu Biomedik Universitas Udayana, Bali.

Wiratama et al. 2013. Kajian Ketahanan Beberapa Galur dan Varietas Cabai terhadap Serangan Antraknosa di Desa Abang Songan Kecamatan Kintamani Kabupaten Bangli. Bali. Program Studi Agroekoteknologi Fakultas Pertanian Universitas Udayana. ISSN: 2301-6515. Vol. 2, No. 